\title{
Folk Medicine among the Mongols in Inner Mongolia ${ }^{1}$
}

\author{
Buyanchuglagin Saijirahu
}

\begin{abstract}
Twenty-first-century Inner Mongolia is characterised by medical pluralism: biomedicine, traditional Chinese medicine, and the Tibetan-derived tradition of Mongolian medicine have parallel roles in the health care system. There is, however, another form of medical practice that has existed in the Mongol society alongside these institutional medicines. In this article, I refer to it as folk medicine. The indigenous tradition of folk medicine has originated from both nomadism and shamanism, and some elements of these old traditions still survive that do not appear to have been influenced by other medical systems. I discuss how nomadic culture produced folk medical practices such as koumiss treatment, immersion therapy and herbal medicine and how shamanic healing practices such as bonesetting and andai therapy are key parts of Mongolian folk medicine, which is related to treating both bodily suffering and illness of the soul. Healing is an important function of Mongolian shamanism, an old religious complex that remains alive within modern society. Folk medicine as a cultural phenomenon has existed from ancient times to our present era. When we attempt to reconstruct the history of Mongolian medicine, we must accept that indigenous knowledge continues to play a role within the medical pluralism of twenty-firstcentury Inner Mongolia.
\end{abstract}

\section{Keywords}

medical pluralism, Mongolian medicine, folk medicine, nomadic culture, shamanic healings, Inner Mongolia

\section{Introduction}

As a part of the changing world order during the twentieth century, the influence of modern science and technology has gradually expanded into the developing world. One example of this has been the impact of modernity on the development of traditional Mongolian medicine during a period in which political control of Inner Mongolia ${ }^{2}$ passed from the Republic of China to

${ }^{1}$ I would like to thank Alex Mckay, Vivienne Lo and Geoffrey Samuel for their warm support, comments and revision in writing this paper.

${ }^{2}$ Inner Mongolia is one of the Autonomous Regions of the People's Republic of China. It was established in 1947, and according to the fifth census in China in the year 2000, the population 
Manchuria (Manzhou Guo or Manchukuo) ${ }^{3}$ under Japanese colonial control, and finally to the People's Republic of China. Fundamental changes in the social and political order, radical cultural transformations, and entirely new scientific policies brought about a new era in traditional medicine in Inner Mongolia. It was integrated with biomedicine in its Chinese form during the last decades of the twentieth century. Medical pluralism, however, is characteristic of Mongolian society in the twenty-first century, with shamanic healers and bonesetters active in both rural and urban areas of Inner Mongolia.

Traditional Mongolian medicine has a long history, throughout which its character has been greatly influenced by cultural exchange with neighbouring peoples. In particular, as a result of the close relationship between the Mongols and Tibet, which dates to at least the thirteenth century, Mongolian medicine assimilated Tibetan medical theory. Such exchanges of medical technology continue today. Recently, some Mongolian practitioners have learned the clinical practice of acupuncture, which comes from traditional Chinese medicine.

In this article, I will focus on some surviving elements of traditional Mongolian medicine that do not appear to have been influenced by other medical traditions and may thus be seen as folk medicine. ${ }^{4} \mathrm{I}$ will begin by outlining the history of Mongolian medicine in order to contextualise its location in the modern medical world.

\section{A brief history of Mongolian medicine}

According to B. Jigmed's work on the development of Mongolian medicine, we may divide its history into three stages. ${ }^{5}$ The first stage is from the ancient

of Inner Mongolia is approximately 23.75 million, of which Mongolians total about 4.03 million (China's Population at the Turn of the Centuries: Neimenggu, Beijing: China Statistics Press, 2005).

3 Manchuria is a mountainous region forming the northeast portion of China, where originally the Tungusic-speaking Manchus, who formed the last imperial dynasty of China (Qing dynasty 1644-1912), lived. Today, the region comprises the provinces of Jilin, Liaoning and Heilongjiang. In 1932, it was declared the independent state of Manchukuo by Japan; this state controlled the eastern portion of Inner Mongolia. It was restored to China in 1945.

4 'Mongolian folk medicine' as used here means that category of medical knowledge not influenced by Indo-Tibetan medical theory. A later tradition that draws on the teachings of Indo-Tibetan medicine is currently known in Mongolia as 'Traditional Mongolian medicine', the term used here. I proceed on the assumption that the category of folk medicine is derived from the (pre-Indo-Tibetan) nomadic and shamanic cultures, in contrast to studies that seek to explain that category in terms of Tibetan and even Western traditions. In some cases, folk medicine and these later traditions have been integrated today in Inner Mongolia.

5 Jigmed 1985, pp. 5-7. 
period of nomadic culture on the Mongolian plateau to the thirteenth century of the common era; the second stage is from the thirteenth to the sixteenth centuries; and the third stage is from the sixteenth to the twentieth centuries. We may now add a fourth stage, from the twentieth to the twentyfirst centuries.

In the first stage, koumiss treatment, bonesetting, immersion and coveringwith-skin therapies were developed. The second period is from the time of the Great Činggis Qayan to the sixteenth century. In this period, Mongolian medicine had not yet been influenced by the theories of Indo-Tibetan medicine. However, the Mongols invaded both the Chinese region and the Tibetan plateau. The third period Jigmed defined is that from the sixteenth century to the twentieth century. In this period, major changes occurred within Mongolian culture due to the introduction and spread of Tibetan Buddhism, which brought with it the Indo-Tibetan medical tradition (sowa rigpa). This third period was one of conflict between Buddhism and Shamanism, as demonstrated in Heissig's studies of Mongolian religions, and the victory of Buddhism at the state level led to the wide diffusion of Tibetan medicine within Mongolia. ${ }^{6}$

This third period saw the formation of Mongolian medical theories drawing on the Tibetan tradition and was, I suggest, the first period of medical pluralism on the Mongolian plateau. Mongols went to Buddhist temples to study Tibetan medicine and translated Tibetan medical literature into Mongolian. These monks graduated from Buddhist medical colleges called Manbarasang ${ }^{7}$ within Buddhist monasteries and adapted Tibetan medicine to Mongolian culture within their own clinical practices. Thus, from this period, we may propose two fields of research: Mongolian folk medical culture, and the Tibetan-derived tradition generally now known as Mongolian traditional medicine. It was this Tibetan-derived medical tradition which led one Japanese scholar to describe Mongolian areas as 'the northern frontier of Ayurvedic medicine'.

A new form of medical pluralism developed during the twentieth century, which I term the fourth stage of Mongolian medical history. During this period, Mongolian medicine, both Tibetan-derived tradition and folk medicine, was integrated and eventually harmoniously coexisted with both biomedicine and

\footnotetext{
${ }^{6}$ Heissig's studies of Mongolian religions date from the 1940s onwards. For more details about the conflict between Buddhism and Shamanism, see Heissig 1980, pp. 1-5.

${ }^{7}$ Manbarasang is the Mongolian collective term for a medical school located in a Buddhist monastery. The term originally comes from the Tibetan term for a monastic medical college, sman pa grwa tshang.

${ }^{8}$ See Toshimitsu (利光有紀) 1989.
} 
traditional Chinese medicine. ${ }^{9}$ This process has been affected by a series of specific tensions - those between Mongolian and Western culture, and those between Mongolian and Han Chinese culture. These occurred against a turbulent political backdrop. After winning its independence from the Qing dynasty in 1911, Outer Mongolia established a fully-fledged Socialist state in 1924. After a long period of struggle for independent statehood, Inner Mongolia became an Autonomous Region of Communist China in 1947.

Thus, while the development of Tibetan medical traditions in Mongolia is a fundamental part of the history of medicine in the Mongolian area, the aim of this article is, however, to demonstrate the history of a distinct and earlier tradition of folk medicine, which is derived from and is related to nomadic and shamanic culture.

\section{Nomadic culture and folk medicine}

The folk medical traditions of the Mongols are a product of the pastoral culture of the Mongolian plateau, with its nomadic economic and political structures and its culture of warfare. Two examples clearly demonstrate this relationship: koumiss treatment and Immersion therapy.

\section{Koumiss treatment}

Koumiss (termed čege or ayira in modern Mongolian) is a kind of fermented liquor prepared from mare's milk. It has traditionally been used both as a popular beverage and as a medicine. Both the Secret History of the Mongols $(\mathrm{SH})^{10}$ and Heida Shilüe (黑韃事略) ${ }^{11}$ record that the Mongols, in the first stage of their medical development, used this drink in order to recover from wounds and to strengthen their bodies. As the Secret History of the Mongols states:

\footnotetext{
${ }^{9}$ I have focused on the twentieth-century history of traditional Mongolian medicine and its multicultural symbols in another article. For example, there are three kinds of hospitals: the general hospital, which incorporates Mongolian, Western and Chinese medical practices, one that exclusively uses Mongolian medicine and one that uses Chinese and Mongolian medical practices. Practitioners of Mongolian medicine, however, sometimes use diagnostic knowledge and instruments from Western medicine and acupuncture meridian points from Chinese medicine when they treat their patients. For more details, see Saijirahu 2007.

${ }_{10}$ The Secret History of the Mongols, a work of unknown authorship, is one of the classics in Mongolian history. It has been argued that the Mongolian sounds in this classic were recorded using Chinese characters in 1240 or in the middle of the thirteenth century.

${ }^{11}$ Heida Shilüe 黑鞋事略 1962, Chapter 41, pp. 504-5. About making and using koumiss, see also Dawson 1955, Chapter 4, pp. 98-9.
} 
In that battle Činggis Qa'an (Qayan) was wounded in a vein of the neck. He could not stop the bleeding and was in a great plight. He waited till sundown, then he pitched camp just there where the two armies had encamped right next to each other.

Jelme sucked and sucked the blood which clogged Činggis Qa'an's (Qayan) wound and his mouth was all smeared with blood. Still, Jelme, not trusting other people, stayed there and looked after him. Until the middle of the night he swallowed down or spat out mouthfuls of the clogging blood.

When midnight had passed Činggis Qa'an (Qayan) revived and said, 'The blood has dried up completely; I am thirsty.' Then Jelme took off his hat, boots and clothes-everything-and stark naked but for his pants, he ran into the midst of the enemy who had settled right next to them. He jumped on to a cart of the people who had set up a circular camp over there. He searched for kumis, but was unable to find any because those people had fled in disarray and had turned the mares loose without milking them.

As he could not find kumis, he took from one of their carts a large covered bucket of curds and carried it back. In the time between his going and coming back he was not seen by anyone. Heaven indeed protected him!

Having brought the covered bucket of curds, the same Jelme, all by himself, searched for water, brought it back, and having mixed it with the curds got the Qa an (Qayan) to drink it.

Three times, resting in between, the Qa'an (Qaran) drank, then he spoke: 'The eyes within me have cleared up. ${ }^{12}$

The tradition of using koumiss to supply the necessary nourishment to the human body was summarised in the Yinshan Zhengyao (飲膳正要1330) ${ }^{13}$ by the famous nutritionist $\mathrm{Hu}$ Sihui (忽思慧). He states that mare's milk is of a cold nature, sweet taste, and prevents thirst and cures fevers. ${ }^{14}$ Scientists have studied the level of nutrients in both mare's milk and koumiss and find that they contain protein, fat, lactose, amino acids, vitamins and trace elements. These studies demonstrated that the level of nutrients in mare's milk is similar to that of human milk, and that koumiss is affected by the fermentation process when its acidity is increased. ${ }^{15}$ Koumiss has been considered to have the ability to prevent tubercular disease and also to treat its early stages. ${ }^{16}$

12 Secret History of the Mongols (SH) 2004, \$145, pp. 65-6.

13 Yinshan Zhengyao 飲膳正要 is a nutrition book for the Mongol empires of the Yuan dynasty compiled by Hu Sihui in 1330. For more details, see 飲膳正要 noted by Liu Yushu 劉 玉書 1986. For the English edition, see Buell et al. 2000.

14 馬乳, 性冷, 甘味, 止渴, 治熱.

15 For more details, see Almas (阿拉木斯) 2003.

16 There have been some studies in the twentieth century regarding the medical effect of koumiss. For example, in the Japanese colonial period of Inner Mongolia in the 1930s, Japanese scientists went to Inner Mongolia to research the medical effects of koumiss for treating tubercular diseases. For more details, see Murata 1936; 1939. See also Kinoshita and Kataoka 1944. 
Today, koumiss is still used in Mongolian medicine. According to Ü. Jamsu (1985) and Sörüngjab, koumiss is used to treat hypertension, apoplexy, heart disease, pulmonary tuberculosis, pulmonary emphysema, gastritis, gastric ulcer, dysentery, diabetes, neurasthenia, neural headache and constipation. ${ }^{17}$ Clinical research into its curative effects has been carried out at the Institute for Mongolian Medicine in Silin-Goul League, Inner Mongolia. ${ }^{18}$

My viewpoint is that ancient nomadic Mongols strengthened their bodies by drinking both mare's milk and koumiss to adapt to a harsh environment and hard battles. This experience has been carried down generation after generation to be developed as a part of folk medicine today.

\section{Immersion therapy}

As a therapeutic measure, immersion therapy in the Mongolian folk medical

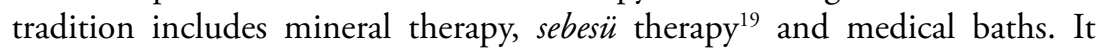
includes not only bathing in natural springs, or herbal medicinal baths, but the use of animal blood, internal organs and hide, to bathe, immerse or compress the affected part of the body. Today, it is one of the traditional five types of treatment used in the Tibetan-derived tradition of Mongolian medical practice-bleeding, cauterizing, immersing and compressing the affected part of body.

Immersion therapy is used to treat conditions regarded as 'cold' ${ }^{20}$ These are limb tremors, contractions and paralysis and arthralgia (ache in joints); gynopathy (gynaecological problems); muscular atrophy (amyotrophy); spleenstomach illnesses such as spleen-stomach disharmony and accumulations of 'wetness-heat' in the spleen and stomach. It is also considered suitable for conditions regarded as 'hot'. ${ }^{21}$ These are fevers due to infection or poison; furuncles, carbuncles, chronic ulcers, swellings and skin diseases. Although nowadays the theory of 'hot' and 'cold' is widely accepted within Mongolian

17 Jamsu 1985, pp. 2-10; Sörüngjab et al. 2002, pp. 801-3.

18 Jamsu 1985; Konagaya 1992, pp. 217-21.

19 Sebesü, also called sebüsü or sebüsün in Mongolian, refers to cud, or partly digested food from the first stomach of a ruminant animal. For instance, that which is returned to the animal's mouth for further chewing.

${ }^{20}$ Cold is a term of clinical and pathological theory in Tibetan-derived tradition of Mongolian medicine today. There is, however, a theory of the unity of opposites of cold and hot, which originated from the indigenous medicine of the ancient nomads in the Mongolian Plateau. There are diseases caused by heat and diseases caused by cold in the common sense categories of Mongolian folk medical knowledge, and clinically, hot diseases are treated by cold medicinal properties and vice versa.

${ }^{21}$ Hot, see cold. 
medicine, this early use of 'hot' and 'cold' originated from the cosmological beliefs, worldview and customs of the early Mongols. For example, the cosmological ideas are dualistic, seeing the opposed natures of the world, such as father heaven (sky) and mother earth (land), spirit and body, life and death, sun and moon, male and female, arya (male or positive element in nature) and bilig (female or negative element), black (shaman) and white (shaman), and hot and cold as basic phenomena of the universe. The idea of opposed natures of the world was very influential for the Mongols, who survive in a cold climate and battle against diseases. Based on the opposed nature of hot and cold, the Mongols used the heat of mutton in the winter to warm up their bodies or heal the chilly stomach, and drank the cold koumiss in the summer to cool their bodies or to 'treat fever disease'.

Historical records support the existence of immersion therapy as a continuing tradition, predating the introduction of Tibetan medical traditions. According to the Chinese sources for the period of the Mongol Empire and the Yuan dynasty, it was widely used by the military. In the Yuan dynasty, for example, the Mongol generals Bu Zhier 布智兒 and Mu Huan 睦歡 are both reported to have been successfully treated by being immersed in hot blood in the belly of freshly slaughtered oxen after losing much of their own blood to arrow wounds. ${ }^{22}$ Several similar accounts may be found in the Yuanshi. For example, the biographies of both Guo Baoyu 郭寶玉 ${ }^{23}$ and Li Ting 李庭, ${ }^{24}$ describe the Mongol military in battle using the practice of healing arrow wounds by placing the victim inside the open belly of an ox. During the Qing dynasty, Chuoerji Moergen 綽爾濟墨爾根, a Mongol military doctor, treated a wounded soldier by placing him into the belly of a white camel. ${ }^{25}$

Cleaves draws attention to linguistic similarities in the terms relating to this treatment that were recorded in the Yuanshi, and the Xinjiang Qazaqs and Ordos Mongols. He also notes that the Mongols used both the sebüsün ${ }^{26}$ and the skin of a freshly killed sheep to heal patients. ${ }^{27}$ Kaszuba cites an example in the Secret History of the Mongols (SH, $\$ 145$; $\$ 173$ ) of sucking the victims' blood from an arrow wound and argues that the Mongols understand blood as a sacred fluid, ${ }^{28}$ able to revive wounded soldiers and quickly return them to battle.

${ }^{22}$ Xin Yuanshi: Bu Zhier Zhuan 新元史·布智兒傳 1935, vol. 26. See also Yuanshi: Bu Zhier Zhuan 元史·布智兒傳 1976, Book No. 10, vol. 123, p. 3021, and Book No.13, vol. 169, p. 3977.

${ }^{23}$ Yuanshi:Guo Baoyu Zhuan 元史·郭寶玉傳 1976, Book No. 13, vol. 149, p. 3521.

${ }^{24}$ Yuanshi:Li Ting Zhuan 元史·李庭傳 1976, Book No. 13, vol. 162, p. 3796.

${ }^{25}$ Qing shigao 清史稿 1977, Book No. 46, vol. 502, p. 13880.

26 See Sebesü (footnote 19).

27 Cleaves 1954.

${ }^{28}$ Kazuba 1996. 
Using the sebes ü of freshly killed ruminants to treat diseases such as arthritis is common in immersion therapy. The hot Sebesü is used to cover the affected part, or the affected part is placed into hot Sebesü. A Qing dynasty source records that Altan Qayan ${ }^{29}$ suffered a foot disease known as tulai (arthritis), which he treated by placing his foot into a freshly killed horse's chest. ${ }^{30}$ This chronicle did not mention the result, but does indicate that the Mongols used such therapies at that time, and since tulai is traditionally remedied by sebesü, we may assume that Altan Qayan placed his foot into the sebesü.

Environmental factors may explain the traditional popularity of immersion therapy. The cold, dry climate tends to induce diseases caused by cold factors. The Chinese medical classic Huangdi neijing:suwen 黃帝內經 - 素問 (Huang dis Inner Canon of Medicine: Basic Questions), describes the North as high and very cold, and its people as living in the open and suffering diseases caused by cold. These conditions are also treated by moxibustion, which is said to have originated in the North, ${ }^{31}$ the Mongolian plateau, where they applied cold remedies to cure conditions seen as 'hot' and hot remedies to cure conditions seen as 'cold'. Jigmed demonstrates that this principle of chill and fever was developed by the famous Mongolian physician Yisibaljuur ${ }^{32}$ in the eighteenth century. In my opinion, however, the early Mongolian usage of 'hot' and 'cold' originated from the indigenous culture of the early Mongols.

Sebesü therapy is used for treating many kinds of symptoms caused by cold factors. The theory of unity of opposites for chill and fever means that conditions classified as 'cold' are treated by applying hot Sebesü. For example, women squat on the rumen ${ }^{33}$ of sheep to treat metropathy caused by coldness, and arthritis is treated by placing the limbs and trunk into the rumen of a sheep. Hot rumen is placed on the trunk of the human body to suck the disease from the visceral organs. ${ }^{34}$

There are also skinning and visceral remedies in which the treatments are similar to sebesü therapy or immersion. The skinning remedy, which is used in

${ }^{29}$ Altan Qayan (1508-82) was a king of the Mongols in the sixteenth century. For his biography, see a work of unknown authorship entitled Altan Qaran-u Turuji (A Biography of a Mongolian King of the Sixteenth Century).

30 Sayang Sečen 1984, p. 432.

31 Huangdi neijing:suwen:yifa fangyi lun 黃帝內經·素問·異法方宜論. See also Jigmed 1985, pp. 28-9.

32 Yisibaljuur (1704-88), a Buddhist monk, was one of the most famous Mongolian physicians. He published Dörben Rasiyan, Four Fountains, a classic text of Mongolian medicine in the eighteenth century. The original work is divided into four books about basic theory, clinical knowledge, medicine and practitioners' morality.

${ }^{33}$ A zoological term for the first stomach of a ruminant, which receives food or cud from the oesophagus, partly digests it with the aid of bacteria and passes it to the reticulum.

34 Saijrah 策·財吉拉胡 1995 , pp. 43-5. 
treating cold symptoms, involves using the skin of a freshly killed animal to cover the trunk of patients or to wrap the diseased areas. Visceral remedies involve using the internal organs of freshly killed sheep; these are placed at the related position of the human body to absorb poisons. When I carried out fieldwork in Eastern Inner Mongolia in the summer of 2005 and 2006, I found that the Mongolian shamans and healers in the Kölön-Buyir region are still applying sebesü and using the skin and internal organs of sheep to treat symptoms caused by cold and moist factors.

In conclusion, these are two cases in which the element of nomadic culture is related to the development of Mongolian folk medical knowledge, such as koumiss treatment and immersion therapy. However, this does not mean these are the only healing skills introduced by the early Mongols that have continued to our generation. I will now consider the Mongolian herbal medicine used by nomads in the thirteenth century. For example, the Secret History of the Mongols (1240) records that Ögelün Üjin (lady Hö'elün), the mother of the future Činggis Qayan, in order to take care of her small sons, foraged for wild plants such as crab or wild apples (ölirsün), bird-cherries (moyilsun), the roots of the great burnet (südün) and silverweed (čičigina), wild garlic (qaliyarsun), wild onion (manggirsun), the bulbs of the wild lily (ja'uqasu) and wild leek (qoqosun). ${ }^{35}$ This means that the early Mongols had the necessary knowledge to dig up and gather wild plants to nourish themselves in response to specific conditions. Both To.Süke and Ruth Meserve have considered the above-listed wild plants as Mongolian herbal medicine and given us botanical, medicinal and historical analysis in great detail. ${ }^{36}$ Furthermore, Hu Sihui listed part of the Mongols materia medica in Yinshan Zhengyao (1330). For example, 赤赤哈納 (čičiryana) was recorded as an herbal medicine. Therefore, medical historian Jigmed emphasises that there was a Mongolian system of food lore and of dietary medicine in the early Mongol culture. ${ }^{37}$

\section{Shamanic tradition and folk medicine}

Although the use of shamanic healing has gradually declined in the face of Tibetan Buddhism, shamanic healers have adapted their practices in line with changes in Mongolian society and culture. One of my shamanic sources told me that they could cure any mental problems arising from ancestors or other

35 The Secret History of the Mongols (SH) 2004, \$74-5, pp. 18-20.

36 Süke 1991; Meserve 2003.

37 Jigmed 1985, pp. 23-7, 43-9. 
spirits through such rituals as Čindan göyüdel-ün darul $\gamma a,{ }^{38}$ which I found to be a living practice in Eastern Inner Mongolia. Mongolian shamanic healing is a part of the folk healings, as is the case, for example, with the bonesetting therapy.

\section{Bonesetting therapy}

Studies have shown that bonesetting ${ }^{39}$ is common in Eastern Inner Mongolia, particularly in Qorčin, as noted by Mongolian medical historian B. Jigmed and the well-known bonesetter Bao Jinshan. ${ }^{40}$ Also in the Kölön-Buyir region, as described by Humphrey and Onon, ${ }^{41}$ and among the Buriats, according to the work of Daniel Hruschka. ${ }^{42}$

In terms of its dynamic theory and clinical skills, bone art in Mongolian medicine appears to predate the influence of Tibetan medicine. It is termed Yasu bariqu jasal (bonesetting therapy), while the bonesetter is known as bariyač $i$ in modern Mongolian. The bonesetter uses his hands to reset broken bones while spraying alcohol from his mouth on to the affected part, which is fixed with small splints. The patient should feel no pain, but is usually advised to rest afterwards. The bones heal quite rapidly.

Culturally, bonesetters are closely related to shamanic practitioners (Mong. böge or böö and uduran), whose healing ability is considered to be a supernatural power bestowed on them by the spirits through worship. Bonesetters have no professional medical training and their skills are either handed down in family lineages, or in some cases, are believed to be imparted by ancestral spirits through dreams. But nowadays bonesetting is considered to be an independent branch of Mongolian medicine, and traditionally the bariyač $i$ are educated neither in biomedicine nor in the Tibetan-derived tradition of Mongolian medicine.

Bonesetting can be traced back to the thirteen century, during the Mongol rule, or even earlier, to the periods of Inner Asian nomadism, but it became prominent during the Qing dynasty (1644-1912), with eminent practitioners such as Chuoerji Moergen 綽爾濟墨爾根, ${ }^{43}$ Jueluo Yisanga 覺羅伊桑阿 ${ }^{44}$ and

38 This is a kind of mental healing ritual held under the instruction of a shaman in the HölönBuyir region to expel the evil spirit from a patient.

39 See Saijirahu 2006.

40 Jigmed 1985, pp. 49-56, 106-10; Bao Jinshan 1984.

41 Humphrey and Onon 1996, pp. 320-4.

${ }^{42}$ Hruschka 1998.

43 Qingshigao 清史稿 1977, Book No. 46, vol. 502, p. 13880.

44 Qingshigao 淸史稿 1977, Book No. 46, vol. 502, pp. 13880-1. 
Naran-Abai (1790-1875), an uduran (female shaman), whose descendants are practising this therapy today. She was famous for her ability to hear the sound of a fractured bone and to squeeze small fragments of broken bone out of the body, as well as her use of a serpent egg-shaped stone ${ }^{45}$ to staunch bleeding and relieve pain. She trained her son, Bao Darma (1835-1909), who also practised koumiss massage. He popularised the art and handed down his healing skills to his three sons.

Today, patients in rural areas have the option of seeking out traditional bonesetters or attending a specialised bonesetting hospital, ${ }^{46}$ or receiving treatment in city hospitals where practitioners are trained not only in the theory of biomedicine but also in the Tibetan-derived tradition of Mongolian medicine. ${ }^{47}$ These hospitals do not, however, have a good reputation.

In practice, Mongolians rarely go to professional bonesetting physicians educated in medical school. There are three main reasons for this. Firstly, the formalities necessary to attend the hospitals are complicated; secondly, treatment in hospitals is too expensive; thirdly, because of the low standard of treatment, the healing process in hospitals is considered to take too much time, compared to that required after treatment by folk bonesetters. In addition, folk bonesetters take care of both the patients and their family members, and thus, develop relationships with these families, creating social networks around folk traditions. ${ }^{48}$

45 The serpent egg-shaped stone, in my view, is clearly a cultural symbol of the authority of bonesetting therapy, which is believed to cure all types of broken bones in lineal bonesetting families in Mongolian society.

46 There is a hospital specialising in bonesetting in the city of Tongliao. Because the bonesetters from the Qorčin region are very famous in this area, the government of the region established the hospital in 1972, and gathered famous shamanic bonesetters at this hospital to deal with the treatment of broken bones. Thirty years later, however, the bonesetters invited by the hospitals have mostly died, and their heirs were not hereditary practitioners, but instead, had been trained in medical school using Western medical instruments and Mongolian herbal medicine. Author interview with the director of the hospital, July 2005.

47 There are three contexts for the treatment of broken bones, according to my fieldwork over the past four years. Firstly, folk bonesetters treat their patients in their own houses in rural areas. These kinds of bonesetters heal broken bones without any kind of formal medical training. Secondly, folk bonesetters offer treatment in clinics or hospitals in urban areas. They treat the patients despite not having any kind of formal medical education, but because of their reputation for excellent healing skills and the needs of clients, the hospitals have invited them to practise in this setting. For example, the hospital of the Institute of Mongolian Medicine in Tongliao in eastern Inner Mongolia has invited a folk bonesetter to treat broken bones at the facility. These above-mentioned types of bonesetters hold a family lineage or are of shamanic descent. Thirdly, practitioners treat broken bones in hospitals using the knowledge and techniques of biomedicine or traditional Mongolian medicine.

${ }^{48}$ I have carried out fieldwork on folk medicine over the past four years, from 2003 to 2006 , in Hohhot, the capital of Inner Mongolia, and eastern Inner Mongolia (both the Qorčin and Hölön-Buyir regions). 
Given the prevailing situation, the Inner Mongolian health administration seeks to persuade the folk bonesetters to undergo medical school training and obtain an official licence before beginning to practise. While consistent with modernisation, this is inconsistent with traditional beliefs in which the supernatural powers held by these practitioners are considered to be the ultimate healing power, with the path to bariyači status dependent on shamanic initiation. Practitioners themselves also seek to retain their traditional lineage patterns of authority.

Traditionally, the succession of bonesetting is a lineage or hereditary system. So a person who wants to be a bonesetter must be born into the family of borjigin $\mathrm{Obo \gamma}$, because the founder of the bonesetting art in the Qorčin region was Naran-Abai uduran. She and her descendants were members of borjigin $O b o \gamma$, the family of Činggis Qayan's clan, which was the leading royal clan. It is believed that a bonesetter who is not born into a branch of this royal family is not a true bariyaci. With this understanding, healers who are not from the borjigin Obor are changing their family names to borjigin in order to be accepted as true bariyači by the Mongolians. But popular acceptance remains dependant on the understanding that a practitioner's power is handed down by their ancestor's spirit.

Borjigin Obo $\gamma$ is both a way of existing in the medical pluralism of today and a cultural code of authority in bonesetting. According to a source, a traditional bonesetting hospital in the Qorčin region invited all borjigin Obor bonesetters to have their knowledge examined at the hospital in the mid1990s. They were asked to diagnose where bones were broken and how the joints were dislocated without seeing the injured parts of the body. The source told me that when she took the test, the spirit of her ancestor came into her body and enabled her to understand what had happened to the patient. She believes in the soul of the snake, which her ancestors have worshipped generation after generation.

My research suggests that the three agencies, the borjigin Obo $\gamma$, the illness ${ }^{49}$ and the spirit-dream are the necessary factors in becoming Qorčin bonesetters. If one of the three features is missing, a bonesetter cannot become a true healer and that absence will usually negatively influence his healing skills. It is notable that some bonesetters today use traditional medications or biomedicine when they heal broken bones. This may be related to China's policy towards traditional medicine, which is to unite it with both traditional medicine and biomedicine.

${ }^{49}$ On the idea of 'shamanic illness' as part of the shaman's initiation, see Eliade 1964, p. 28. 
By comparison, China has sought to integrate traditional medicine with biomedicine since the 1940s, even before the establishment of the People's Republic in 1949. So the integration of Chinese and Western Medicine has appeared in the Han Chinese region. However, there has been another kind of integration in the pluralistic medical world of Inner Mongolia. Traditional Mongolian medicine, including folk medicine, has been integrated with biomedicine and Chinese medicine. In some cases, the folk bonesetters have used their knowledge of the other three medical systems as a means of maintaining their traditions in the modernisation of Inner Mongolia. For example, some bonesetters have used Mongolian materia medica or the intravenous drip in order to assist in their patients' recovery. On the other hand, some bonesetters, such as Bao Jinshan and Wangčinjab, have interpreted bonesetting through the anatomical knowledge of biomedicine and the theory of Tibetan-originated Mongolian medicine. ${ }^{50}$ They are reluctantly adopting the methods and understanding of scientific rationality alongside the emotional aspects of the indigenous tradition. Thus, the folk bonesetter is a cultural symbol standing on the border between science and religion. In the face of biomedical development, cultural nationalism has acted to preserve traditional medicine in the health care system in Inner Mongolia, and promises to do so in the future.

As a religio-medical culture, shamanic healing in Inner Mongolia plays an important role in the health care system of Mongolian society. Bonesetting, biomedicine and shamanic healing are all becoming more visible in the new era of medicine.

\section{Andai Therapy}

Andai denotes both mental illness and its treatment, and is both a cultural sign and a kind of folkdance that remains popular amongst the Mongolians of eastern Inner Mongolia. Here, I would like to briefly discuss its history, the causation of the illness, the method of healing and its cultural meaning and beliefs related to the history of folk medical practice.

Andai therapy is derived from Mongolian shamanism. There are, however, different viewpoints on its origin and history. Some have argued that it can be traced back to the seventeenth century in eastern Inner Mongolia. ${ }^{51}$ This

\footnotetext{
${ }^{50}$ Bao Jinshan 1984, pp. 5-46; Wangčinjab 1997, pp. 104-15.

${ }^{51}$ Konagaya 1992, p. 198. In my opinion, the original form of the Andai dance was the dancing custom of ancient Mongols who danced around the savlarar modu, an old sacred branching tree. The Secret History of the Mongols records that when the leader of Mongols called Qutula was made a king, the Mongols danced round about the Branching Tree until there was a ditch up to their ribs and dust up to their knees (Cleaves 1982, p. 14).
} 
region is a semi-agricultural and semi-pastoral area influenced by Chinese culture and Tibetan Buddhism. Mongols in that area would gather to dance and sing under a shaman's instruction in order to treat young women's mental problems. Others argue that the dance comes from a Shamanic myth that describes a herdsman whose daughter had a mental problem..$^{52}$ In order to treat her sickness, he took her to a doctor who could heal that kind of illness, but the doctor failed. Finally, they met a shaman who cured her sickness with the andai dance. In another version, the Mongols held a ceremony to celebrate the rich fruits of hunting and stockbreeding, with a kind of public dance called andai, which treated mental problems. ${ }^{53}$

The word andai has several possible meanings in Mongolian. One of the meanings comes from the Mongolian word öndeikü, which means 'standing up' and it is believed by some that andai is derived from this word. Another theory is that the word andai comes from the word anda, meaning 'sworn brothers', friends or male companions. Finally, some suggest that the word andai comes from the word $a d a$, meaning an 'evil demon or spirit'. It is believed that when a person is possessed by an ada, they will have a mental problem, an incurable disease called ada orusiqu. Both Banzarov and Heissig understood $a d a$ as a spirit that flies through the air, frightens men, spreads illnesses and inspires frenzied passions. ${ }^{54} \mathrm{I}$ have argued that the symptoms of ada orusiqu are similar to the symptoms of andai illness. ${ }^{55}$

Patients who have andai illness are generally married or unmarried women aged 18-25 years. During my recent field research, I could still find people who used to have the illness and shamans who used to treat it in the 1940s. It is commonly thought that the illness comes from a mental disorder, such as failed marriage or sterility, or from the problem of women getting used to an unfamiliar community order after marriage. In summary, the gender problem, the conflict between individuals, and contradictions between personality and community were the main problems. In shamanic understanding, however, the causation of the illness was considered to be due to the action of both the souls of amphibious creatures (dragon, frog or crocodile) and lost souls (or ghosts, the souls of people who died in their early days), so the ritual was held at the instruction of the shaman to drive away the illness possessing the patient.

52 Načinšongqur 2001, pp.1-23.

53 The Shamanic myth about Andai is an oral tradition recorded first in Čigči's Andai (Čigči et al. 1984). However, I found a similar oral tradition very popular amongst the Mongols in the Küriye banner of Tongliao city.

54 Banzarov 1981; Heissig 1980, p. 15.

55 See Saijirah 財吉拉胡 2005, pp. 105-9. 
According to my fieldwork in the summer of $2005^{56}$ and some earlier studies on andai, ${ }^{57}$ there are several symptoms. Due to mental problems, a part of the body becomes numb, unconscious movements are made, or the patient will have a reduced appetite and digestion problems. In more extreme cases, the patient may become speechless, cry wildly, or dance and sing wildly. In addition, some researchers believe that according to the theory of Mongolian medicine, such symptoms are caused by cold factors (for example, chill, slow pulse) of badran combined with kei (one of the three elements) [Mong. kei, sir- $a$ and badran of the human body], or the three causes of diseases in the medicine [Tib: rlung, mkhris-pa and bad-kan])..$^{58}$

Although the theory of Tibetan-derived tradition of Mongolian medicine explained the symptoms of andai, there was no method to cure the illness in the medicine. Only shamans in eastern Inner Mongolia could cure the illness. They used a special ritual that was not a practice of Tibetan-derived tradition of Mongolian medicine to treat women's mental problems. After the specialist shaman diagnosed the illness, the place and the time of treatment were selected. Then, the young men of the community who were skilled at the andai dance were asked to join the rite. They sang the special songs and performed the special dances around the female patient under the shaman's supervision. Affected by both the words and the melodies of the andai dance within the shamanic atmosphere, the client started to dance with the crowd of young men. Then, the patient began sweating and gradually recovered from the mental problem. The period of treatment may be one week or longer. At the end of the rite, a paper-made effigy was burnt by the practitioner. It was called Jolir yarraqu, ${ }^{59}$ which means to conjure the possessed andai from the client's body with the power of the shaman's ancestor's spirit and sacred fire. In short, this treatment is shamanic psychotherapy combined with the physical exercise therapy to heal the pain of Mongolian young married women's mental problems. ${ }^{60}$

Andai therapy makes use of a number of well-studied Mongolian cultural themes. For example, because this treatment has been combined with folkdance

\footnotetext{
${ }^{56}$ In order to carry out medical anthropological research into Mongolian shamanic healing in eastern Inner Mongolia, I have been doing field research since 2001. Since then, I have taken advantage of the summer holiday every year to do my fieldwork in eastern Inner Mongolia.

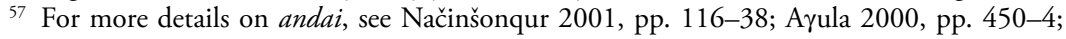
Konagaya 1992, pp. 156-200.

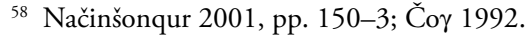

${ }^{59}$ A jolir is a figurine, usually made of dough or paper, which is used in religious (Lamaistic or Shamanic) ritual for ridding one of evil spirits causing illness. Jolir yarraqu means to dispose of a joli by burning or throwing it away in a ritual of praying for a sick person.

${ }^{60}$ For more details about andai ritual, see Čigči et al. 1984 and Načinšongqur 2001.
} 
and folksong under the instruction of specialist shamans, there is a link between healing and Mongolian folklore. Also, because of the involvement of the shamans, there is a connection to Mongolian religious study.

\section{Conclusion}

The society of nomadic Mongols, especially in Inner Mongolia, has been gradually changed by the influence of exotic cultures from the borderland and the variations of culture in the globalised world. These changes have brought both cultural tension and cultural nationalism to the Mongols in Inner Mongolia. Traditional medicine (for instance, both the Tibetan-derived tradition of Mongolian medicine and folk medicine) has been promoted by the Mongols as national heritage and accepted as an authority of the tradition, although there is the process of pluralistic medicine in the twentieth century, with the rapid popularisation of modern medicine. This acceptance can be a means of survival for traditional medicine, or at least this is the argument advanced by practitioners. From another perspective, however, another medical system, paralleled with the above-mentioned medicine, has existed as a part of the Mongols' culture (referred to as folk medicine in this article). There are clients or patients who have supported this system through their beliefs in religious culture. This folk medicine, due to client needs, has continued to play a role in the health care system in both rural and urban areas of Inner Mongolia.

We have noted that nomadic culture produced folk medical practices such as koumiss treatment, immersion therapy and herbal medicine and that shamanic healing is a key part of Mongolian folk medicine. We have argued that shamanic healing is related to treating bodily suffering and illness of the soul. Folk medicine as a cultural phenomenon has existed from ancient times to our present era. When we attempt to reconstruct the history of Mongolian medicine, we must accept that indigenous knowledge has continued to play a role within the medical pluralism of twentieth-century Inner Mongolia.

\section{References}

\section{Primary sources}

Altan Qayan-u Turuji (A biography of Altan Qayan, a Mongolian King of the sixteenth century) 1983 (1607), Reprint-Hohhot: Inner Mongolia People’s Press.

Hanshu: Lilezhi 2, 漢書 ・禮樂志第二 (History of Han Dynasty, Lilezhi No. 2, Book No. 4, vol. 22), Ban Gu 班固, Reprint-Beijing: Zhonghua shuju 中華書局, 1976. 
Heida Shilüe 黑韃事略 (The Brief Outline of the Affairs of the Black Tatar), Peng Daya 彭大雅 1237 CE completed, in Wang Guowei 王國維, editor, Menggu shiliao sizhong 蒙古史料四種, Zhengzhong shuju 正中書局, Taibei 台北, 1962.

Huangdi neijing:suwen 黃帝內經·素問 (Huang dis Inner Canon of Medicine: Basic Question), Reprint-Beijing: People's Medical Publishing House, 1977.

Qad-un ündüsün-ü erdeni-yin tobči (蒙古源流 The Precious Button of the Origin of the Sovereigns), Sarang Sečen, Reprint-Hohhot: Inner Mongolia People’s Press, 1984.

Qingshigao 清史稿 (Manuscript History of Qing Dynasty, Book No. 46, vol. 502), Zhao Erxun 趙爾巽 et al., Reprint-Beijing: Zhonghua shuju 中華書局, 1977.

Shiji:Xiongnu Zhuan 史記 - 匈奴傳 (Shiji. The Biographies of Xiongnu, Book No. 1, Shiji vol. 110, in The Twenty Five Histories 二拾五史), Sima Qian 司馬遷, Reprint-Shanghai: Shanghai Guji Press and Shanghai Shudian, 1986.

The Biography of the Tibetan Physician G'yu-thog Yon-tan-mgon-po the Elder, Japanese translation from Tibetan text by Kazunari Nakagawa, Tokyo: Iwanami Syoten, 2001.

The Mongol Mission: Narratives and Letters of the Franciscan Missionaries in Mongolia and China in the 13th and 14th Centuries (translated by a nun of Stanbrook Abbey; edited and with an introduction by Christopher Dawson), London and New York: Sheed and Ward, 1955.

The Secret History of the Mongols (SH) 1982, translated by F. W. Cleaves, Cambridge MA: Harvard University Press.

The Secret History of the Mongols: A Mongolian Epic Chronicle of the Thirteenth Century (SH) 2004, translated with a historical and philological commentary by Igor De Rachewiltz, Leiden: Brill NV.

Xin Yuanshi:Bu Zhier Zhuan 新元史・布智兒傳 (New History of Yuan Dynasty. The Biography of Bu Zhier, vol. 26), Ke Shaomin 柯劭莣, Reprint-Shanghai: Shanghai Kaiming Publishing, 1935.

Yinshan Zhengyao 飲膳正要 (vols 1-3), Hu Sihui 忽思慧 1330 CE completed, this version was noted by Liu Yushu 劉玉書, Reprint-Beijing: People's Medical Publishing House, 1986; P. D. Buell, E. N. Anderson and C. Perry, A Soup for the Qan: Chinese Dietary Medicine of the Mongol Era as seen in Hu Szu-huis Yin-shan Cheng-yao, London: Kegan Paul International (Sir Henry Wellcome Asian Series), 2000.

Yuanshi: Bu Zhier Zhuan 元史·布智兒傳 (History of Yuan Dynasty. The Biography of Bu Zhier, Book No. 10, vol. 123), Song Lian 宋濂 et al., Reprint-Beijing: Zhonghua shuju 中華書局, 1976.

Yuanshi: Guo Baoyu Zhuan 元史·郭寶玉傳 (History of Yuan Dynasty. The Biography of Guo Baoyu, Book No. 13, vol. 149), Song Lian 宋濂 et al., Reprint-Beijing: Zhonghua shuju 中華書局, 1976.

Yuanshi: Li Ting Zhuan 元史·李庭傳 (History of Yuan Dynasty. The Biography of Li Ting, Book No. 13, vol. 162), Song Lian 宋濂 et al., Reprint-Beijing: Zhonghua shuju 中華書局, 1976.

Yuanshi: Xie Zhongwen Zhuan 元史·謝仲溫傳 (History of Yuan Dynasty. The Biography of Xie Zhongwen, Book No. 13, vol. 169), Song Lian 宋濂 et al., Reprint-Beijing: Zhonghua shuju 中華書局, 1976.

\section{Secondary sources}

Almas (阿拉木斯) 2003, 'A Study on the Dynamic Variety of Horse Yoghurt Nutrients during the Fermentation Process', paper for a Master degree submitted to Inner Mongolia Agricultural University, Hohhot, China.

A $\gamma u$ ua, B. 2000, Traditional Therapy in Mongolian Medicine, Chifeng: Inner Mongolia Science and Technique Press. 
Banzarov, Dorji 1981, 'The Black Faith, or Shamanism among the Mongols (1846)', translated from the Russian by Jan Nattier and John R. Krueger, Mongolian Studies, 7: 53-91.

Bao Jinshan 1984, Ulamjilaltu Yasun Jasal (Traditional Bonesetting Therapy), Hohhot: Inner Mongolia People's Press.

Bold, Sharav and Ambaga, Miegombo 2002, History and Fundamentals of Mongolian Traditional Medicine, Ulaanbaatar, Mongolia.

Buell, P. D., Anderson, E. N. and Perry, C. 2000, A Soup for the Qan: Chinese Dietary Medicine of the Mongol Era as seen in Hu Szu-hui's Yin-shan Cheng-yao, London: Kegan Paul International.

Caijilahu, C. 策·財吉拉胡 1999, 'Influence of Religious Belief on Mongolian Medicine', Chinese Journal of Medical History, 29:2, 92-5.

Čigči et al. 1984, Andai, Hohhot: Inner Mongolia People’s Press.

Cleaves, F. W. 1954, 'A Medical Practice of the Mongols in the Thirteenth Century', Harvard Journal of Asiatic Studies, 17: 428-44.

1982, The Secret History of the Mongols (SH) 1982, Cambridge, MA: Harvard University Press.

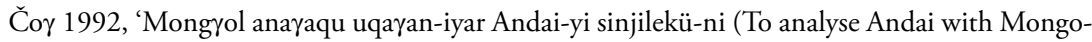
lian Medicine)', Academic Journal of Inner Mongolia Normal College for Nationalities, 39: $113-22$.

Dawson, C. (ed.) 1955, The Mongol Mission: Narratives and Letters of the Franciscan Missionaries in Mongolia and China in the 13th and 14th Centuries, London and New York: Sheed and Ward.

Eliade, M. 1964 (1951), Shamanism: Archaic Techniques of Ecstasy, Princeton: Princeton University Press.

Good, B. J. 1994, Medicine, Rationality, and Experience, Cambridge: Cambridge University Press.

Heissig, W. 1980 (1970), The Religions of Mongolia, translated from the German edition by Geoffrey Samuel, University of California Press.

Hruschka, D. J. 1998, 'Baria Healers among the Buriats in Eastern Mongolia', Mongolia Studies, 21: 21-44.

Humphrey, C. and U. Onon 1996, Shamans and Elders: Experience, Knowledge, and Power among the Daur Mongols, Oxford: Clarendon Press.

Jamsu, Ü. 1985, Čege-yin Jasal (Koumiss Therapy), Hohhot: Inner Mongolia People’s Press.

Jigmed, B. 1985, Mongrol Anaraqu Uqaran-u Tobci Teüke. (A Brief History of Traditional Mongolian Medicine), Chifeng: Inner Mongolia Science and Technology Press.

Kazuba, S. C. 1996, 'Wounds in Medieval Mongol Warfare: Their Nature and Treatment in the Secret History, with some notes on Mongolian Military Medicine and Hygiene', Mongolian Studies, 19: 59-67.

Kinoshita Yoshito and Kataoka Hiroshi 1944, 'Haikekkaku kanzya ni okeru kumisu ryouhou no zikken teki kenkyu (An experimental research on koumiss treatment for pulmonary tubercular), Nihon igaku (Japanese Medicine), 364: 177-82.

Konagaya Yuki 1992, Mongoru mangekyo (『モンゴル万華鏡』The Culture of the Mongols), Tokyo: The Kakugawa Press.

Meserve, R. I. 2003, 'On the History of Medicinal Plant Research in Mongolia', Remota Relata, Studia Orientalia, 97: 155-67.

Murata Syousei 1936, 'Kekkaku chiryou tositeno kumisu no kentou (Analysing koumiss as a tubercular treatment)', Tokio izi sinsi (Tokyo Medical Journal), 2978: 47-8.

_ 1939, 'Kekkaku ni kansuru kumisu seizai: 'Bio kumisu' zikken rei (A case experiment about Koumiss formulation called bio-koumiss for tubercular', Tokio izi sinsi (Tokyo Medical Journal), 2981: 48-51. 
Načinšongqur 2001, Andai-yin soyul sudulul (The Cultural Study on Andai), Hailar: Inner Mongolia Culture Press.

Saijrah, Ch. 策·財吉拉胡 1995, 'Development of Immersion Therapy in Mongolian Medicine', Chinese Journal of Medical History, 25:1, 43-5.

Saijirah, Ch. 財吉拉胡 2005, 'On Andai Therapy in Traditional Mongolian Medicine', Chinese Journal of Medical History, 35:2, 105-9.

Saijirahu, B. 2006, 'Traditional Bonesetting Therapy in Eastern Inner Mongolia', Alternative Medicine, 1: 62-9.

Saijirahu 財吉拉胡 2007, 'On the Development of Traditional Mongolian Medicine in Twentieth-Century Inner Mongolia', Chinese Journal of Medical History, 37:2, 88-93.

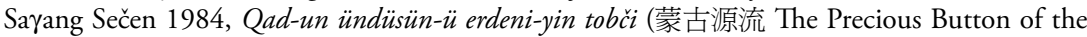
Origin of the Sovereigns), Reprint-Hohhot: Inner Mongolia People's Press.

Sörüngjab et al. 2002, Mongrol sudulul-un nebterkei toli-Anaraqu uqaran (Encyclopedia of Mongolology: Medicine), Hohhot: Inner Mongolia People’s Press.

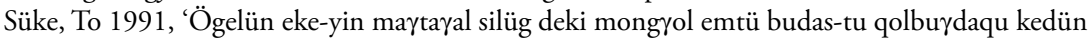
neres-ün tuqai' (On the names related to Mongolian materia medica appearing in the hymnic poem of Mother Ögelün), Journal of Inner Mongolia Social Science, 3: 25-38.

Toshimitsu Yuki 1989, 'The North Front of Ayurveda: Introduction of Mongolian Medicine', Studies of Medical History, 63 (『医学史研究』): 19-22.

Wangčinjab 1997, Mongrolcud-un yasu bariqu uqaran (Mongolian Bonesetting Therapy), Shenyang: Liaoning Nationalities' Press. 